\begin{tabular}{|c|c|c|}
\hline \multirow{2}{*}{$\sqrt{\mathrm{VT}}$} & $\begin{array}{l}\text { International Journal of Current Research in } \\
\text { Biosciences and Plant Biology }\end{array}$ & \\
\hline & Volume $5 \bullet$ Number 3 (March-2018)・ISSN: 2349-8080 (Online) & \\
\hline $\begin{array}{l}\text { EXCELLENT } \\
\text { PUBLISHERS }\end{array}$ & Journal homepage: www.ijcrbp.com & \\
\hline
\end{tabular}

Review Article

doi: https://doi.org/10.20546/ijcrbp.2018.503.002

\title{
Symplocos paniculata Miq. - A Review
}

\author{
G. Kusuma1, B. Vijaya Kumar² and S. Chitra ${ }^{3 *}$
}

${ }^{1}$ Research Officer (Ay.) /Scientist-2, Captain Srinivasa Murthy Regional Ayurveda Drug Development Institute, CCRAS, Ministry of AYUSH, Govt. of India, A.A. Hospital Campus, Arumbakkam, Chennai-600 106, Tamil Nadu, India

${ }^{2}$ Department of Chemistry, Vel Tech High Tech Dr. Rangarajan Dr. Sakunthala Engineering College, Avadi, Chennai-600 062, Tamil Nadu, India

${ }^{3}$ Assistant Director (Biochemistry), Captain Srinivasa Murthy Regional Ayurveda Drug Development Institute, CCRAS, Ministry of AYUSH, Govt. of India, A.A. Hospital Campus, Arumbakkam, Chennai-600 106, Tamil Nadu, India

${ }^{*}$ Corresponding author.

\begin{tabular}{|c|c|}
\hline AIt & \\
\hline $\begin{array}{l}\text { Date } \\
06 \mathrm{M}\end{array}$ & \multirow{3}{*}{$\begin{array}{l}\text { Historically plants have played an important role in medicine. Medicinal herbs are } \\
\text { moving from fringe to mainstream use with a greater number of people seeking } \\
\text { remedies. Through observation and experimentation, human beings have learnt that } \\
\text { plants promote health. The use of these herbal remedies is not only cost effective but } \\
\text { also safe and almost free from serious side effects. The genus Symplocos has been } \\
\text { reviewed for its chemical constituents and biological activities including traditional } \\
\text { importance of some common species. Symplocos paniculata is an evergreen Ayurvedic } \\
\text { plant, with wide range of ethno medicinal uses including treatment for dysentery, } \\
\text { bowel complaints, inflammations, snake bites, vaginal discharges and miscarriages. } \\
\text { From various literatures the crude extracts of S. paniculata possess different kinds of } \\
\text { biological functions studied by researchers through phytochemical, pharmacological } \\
\text { and biochemical investigations. }\end{array}$} \\
\hline $\mathrm{Ke}$ & \\
\hline Symp & \\
\hline
\end{tabular}

\section{Introduction}

The genus Symplocos consists of almost 300-500 species. These plants are distributed in tropical and subtropical area in Asia, Malaysia, and America ${ }^{1}$. In recent years, an extensive work in chemistry and pharmacology on the genus Symplocos has been recorded. Symplocos is one of the most selected genera having potential medicinal values. Two species in the genus Symplocos namely Symplocos paniculata Miq. and Symplocos racemosa Roxb. are widely used in Ayurveda and are known as Pattika lodhra and Savara lodhra respectively in Sanskrit. Savara lodhra- $S$. racemosa is extensively used in therapeutics for various diseases whereas Pattika lodhra- S. paniculata is less known among Ayurvedic fraternity though mentioned in various classical texts of Ayurveda. The properties of $S$. paniculata are the same as those of $S$. racemosa; but of the two species $S$. paniculata is the better therapeutically ${ }^{2}$. The presence of easily separable plates (Pattika) of tissues in the inner bark ${ }^{3}$ (Fig.1) and due to its thick nature (Sthulavalkalah in Sanskrit), S. paniculata got the name Pattika lodhra. Other than the thick nature 
of the bark the synonyms do not give any indication that may help to identify the botanical source of
S.paniculata ${ }^{4}$. Pattika lodhra is commonly known as Asiatic Sweet leaf, Sapphire berry (Fig.2).

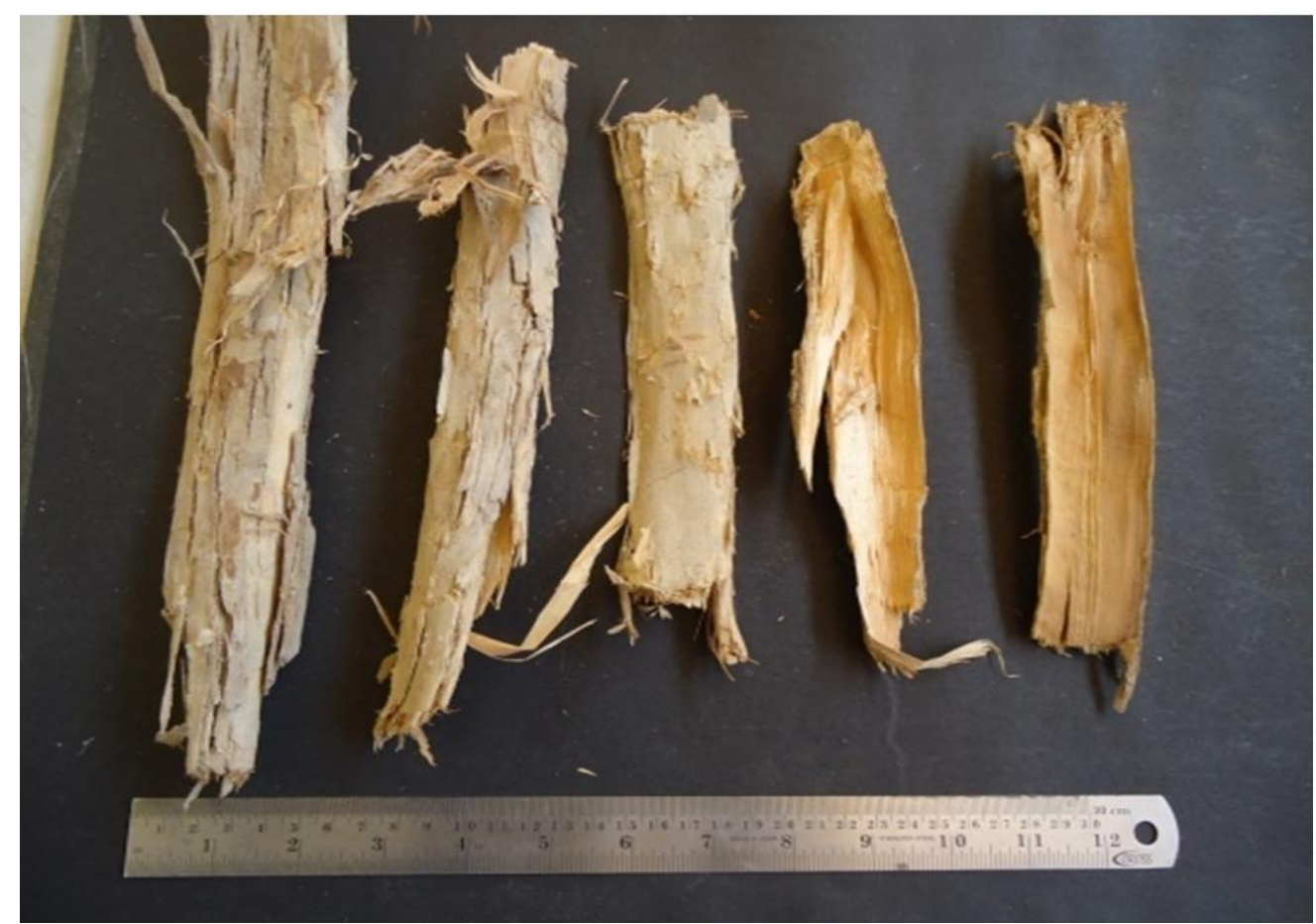

Fig. 1: Stem bark of Symplocos paniculata.
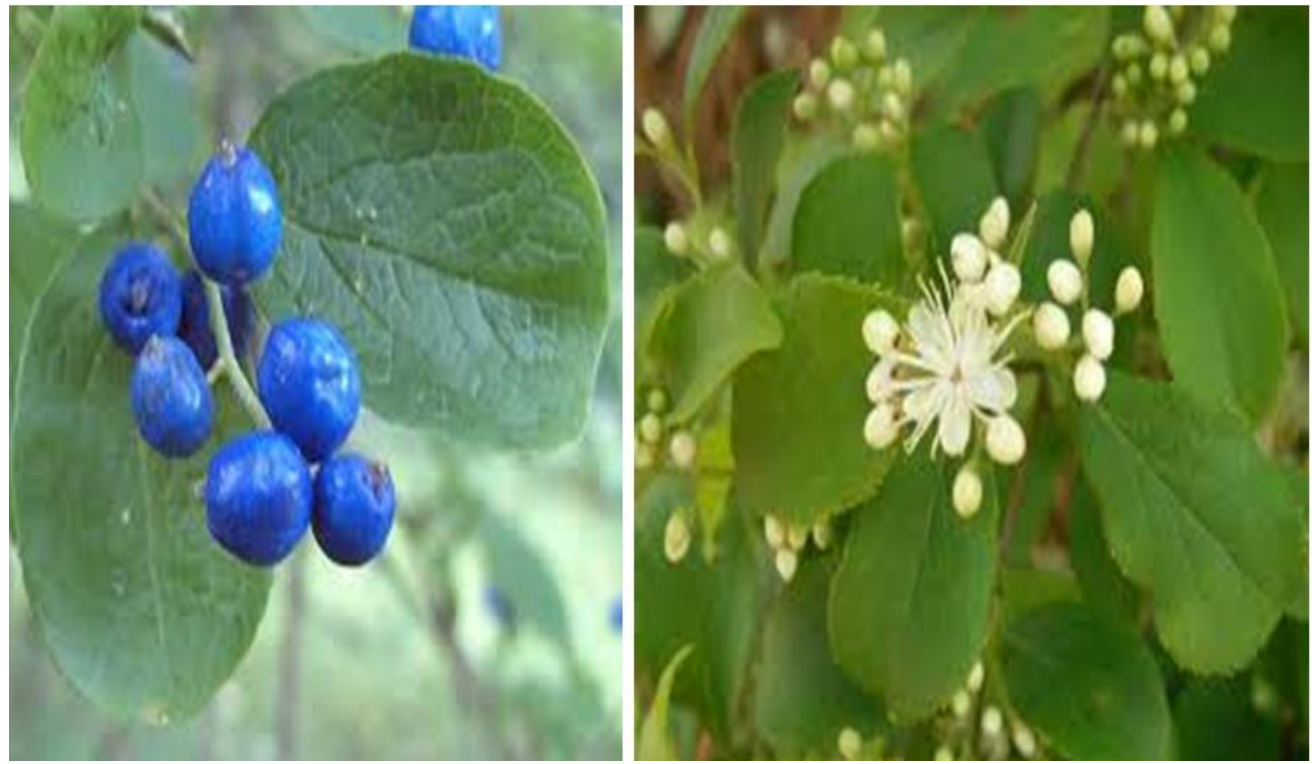

Fig. 2: Fruiting and flowering branches of Symplocos paniculata.

Certain Ayurvedic formulations like Nyagrodhadi Kwatha churna contain both Savara lodhra and Pattika lodhra as ingredients. The knowledge about Pattika lodhra is absolutely necessary as it throws light on its identity which will be useful further in authenticating the drug in drug standardization. $S$. paniculata Miq is sold in the market under the name Lodhra. The common names of S. paniculata ${ }^{2}$ and its 14 accepted scientific synonyms ${ }^{5}$ are given in Tables 1 and 2. 
Table 1. Vernacular names of S. paniculata.

\begin{tabular}{lll}
\hline $\begin{array}{l}\text { S. } \\
\text { No. }\end{array}$ & $\begin{array}{l}\text { Name of } \\
\text { the Place / } \\
\text { Language }\end{array}$ & Vernacular Names \\
\hline 1. & Basharh & Lojh \\
2. & Burma & Daukyat \\
3. & Jaunsar & Lodh, lodra \\
4. & Kumaon & Lodh \\
5. & Punjab & Laudar, Lodar, Lodh, Loj, Loja, \\
& & Lu, Pathani \\
6. & Sind & Lodh, Lodur, Pathani \\
7. & Hindi & Ludh \\
8. & Sanskrit & Akshibheshaja, Bahulatvacha, \\
& & Brihaddala, Brihadvalka, \\
& & Brihatpatra, Galava, Jirnabudhna, \\
& & Jirnapatra, Kramuka, \\
& & Lakshaprasada, Lakshaprasadana, \\
& & Lodhra, Patti, Pattikakhya, \\
& & Pattikalodhra, Shabara, \\
& & Shirnapatra, Shvetalodhra, \\
& & Sthulavalkala, Valka, \\
& & Valkalodhra \\
\hline
\end{tabular}

Table 2. Accepted scientific synonyms for Symplocos paniculata Miq.

\begin{tabular}{cl}
\hline S. & Scientific Synonyms \\
No. & \\
\hline 1. & Cotoneaster coreanus H. Lév. \\
2. & Myrtus chinensis Lour. \\
3. & Palura chinensis (Lour.) Koidz. \\
4. & Palura chinensis var. pilosa Nakai \\
5. & Palura sinica (Ker Gawl.) Miers \\
6. & Prunus mairei H.Lév. \\
7. & Prunus paniculata- Thunb. \\
8. & Symplocos chinensis - (Lour.) Druce. \\
9. & Symplocos chinensis var. vestita (Hemsl.) Hand.- \\
& Mazz. \\
10. & Symplocos crataegoides Buch.- Ham. ex D. Don \\
11. & Symplocos hunanensis Hand.-Mazz. \\
12. & Symplocos simaoensis Y. Y. Qian \\
13. & Symplocos sinica var. vestita Hemsl. \\
\hline
\end{tabular}

\section{Distribution}

S. paniculata is distributed in Himalaya up to 9,000 feet from the Indus to Assam, Khasia hills, upper and lower Burma, Punjab occurring in high altitudes between 600 and 2,400 $\mathrm{m}^{2,6}$.

\section{Morphology}

S. paniculata is a large deciduous shrub or medium sized tree of $12 \mathrm{~m}$ in height. Young branches more or less pilose. Leaves are membranous of around 5$10 \mathrm{~cm}$ long, elliptic or ovate-elliptic, acute or acuminate, rounded or cuneate at the base, usually deeply serrate towards the apex, under surface usually pilose especially on the midrib, but sometimes quite glabrous, nerves are prominent situated beneath the petioles are of $5 \mathrm{~mm}$ in length. Flowers are pedicelled, white turning yellow, fragrant, arranged in cymose corymbs on elongate terminal and axillary panicles, those of the lateral branches often few and with longer pedicels; bracts small, linear, caduceus. Calyx-tube obconic, glabrous, more or less pilose; lobes rounded or lanceolate and acute, ciliate. Wood-white, soft to moderately hard, close grained, liable to twist and split when seasoning. Corolla three times longer than the calyx 5 in number. Stamens are 20-60 in number, equaling the corolla in length; filaments connate in 5 bundles. Ovary usually 2-celled, glabrous or hairy. Fruits are of $3-8 \mathrm{~mm}$ in size, globose or ovoid, crowned with the remains of the calyx-limb, fruits blue and turned black on ripe, usually one seeded ${ }^{2}$.

Flowering time of the plant is around May-June and fruiting season is during October-December ${ }^{7}$. The useful part of the plant is reported to be bark.

\section{Cultivation}

Cultivation of $S$. paniculata requires an acid soil and a sunny position. Succeeds in a sunny position in any well-drained fertile neutral to acid soil ${ }^{8,9}$. These plants are hardy to about $-10^{\circ} \mathrm{C}$, though it can survive in quite harsh winters but they need a warm, sunny protected position and a hot summer if they are to fruit well 9,10 . Being self-sterile, it requires cross-pollination with a different plant in the same species if seed and fruit are to be produced. Plants in this genus are notably resistant to honey fungus. Pidorus euchromioides Walker (Lepidoptera; Zygaenidae) is a significant defoliator of Chinese sweet leaf, S. chinensis (Symplocaceae), 
in Nanchang Jiangxi Province, People's Republic of China ${ }^{11}$. Overwintering larvae hibernate underground litter and become active just as the leaf buds of the host plant, $S$. chinensis, are opening, usually in early April and cause damage to the tender buds in early spring ${ }^{12}$.

\section{Propagation}

Seed-best sown in a cold frame as soon as it is ripe. Stored seed requires stratification and is best sown in a cold frame in late winter; it can take 12 months to germinate ${ }^{10}$. Prick out the seedlings into individual pots when they are large enough to handle and grow them on in the cold frame for their first winter. Plant out in late spring or early summer. Cuttings of half-ripe wood, 7-10 cm with a heel, July/ August in individual pots in a cold frame. Roots are formed in about 4 weeks ${ }^{9,13}$.

\section{DNA bar coding of $S$. paniculata}

The consortium for the Barcode of Life (CBOL) in the 2009 has recommended $r b c L$, matKand $p s b A$ $\operatorname{trnH}$ as the core DNA markers in the identification of plant species. The ribulose-1, 5-bisphosphate carboxylase large subunit $(r b c L)$ and maturase $\mathrm{K}$ (matK) for $S$. paniculata has been sequenced and stored at the National Center for Biotechnology Information (NCBI) under the accession numbers GenBank: HQ427234.1 and GenBank: HQ427378.1 (Unpublished). The psbA-trnH intergenic spacer and partial sequence for the internal transcribed sequence (ITS2) of $S$. paniculata has been used for the study of phylogenic analysis of Asian Symplocos (Symplocaceae) based on nuclear and chloroplast DNA sequences. These sequences are stored in GenBank: AB115370.1 and AY336263.1 ${ }^{14}$. These sequences will be used in the identification of $S$. paniculata.

\section{Chemical Constituents of $S$. paniculata}

The plants of genus Symplocos contain a variety of constituents viz. terpenoids, flavonoids, lignans, phenols, steroids, alkaloids, iridoids, and many others $^{15}$. Ursolic acid, corosolic acid and $2 \alpha, 3 \alpha$, $19 \alpha, 23$-tetrahydroxyurs-12-ene-28-oic acid (Figs. 3 and 4$)^{16}$, flavonoids ${ }^{17}$ are reported to be present in $S$. paniculata. Besides some triterpenoids, triterpenoid saponins ${ }^{18}$, flavanol glycosides ${ }^{19}$, iridoid glycosides ${ }^{20}$ and lignan glycosides ${ }^{21}$, isolated from Symplocos genus.
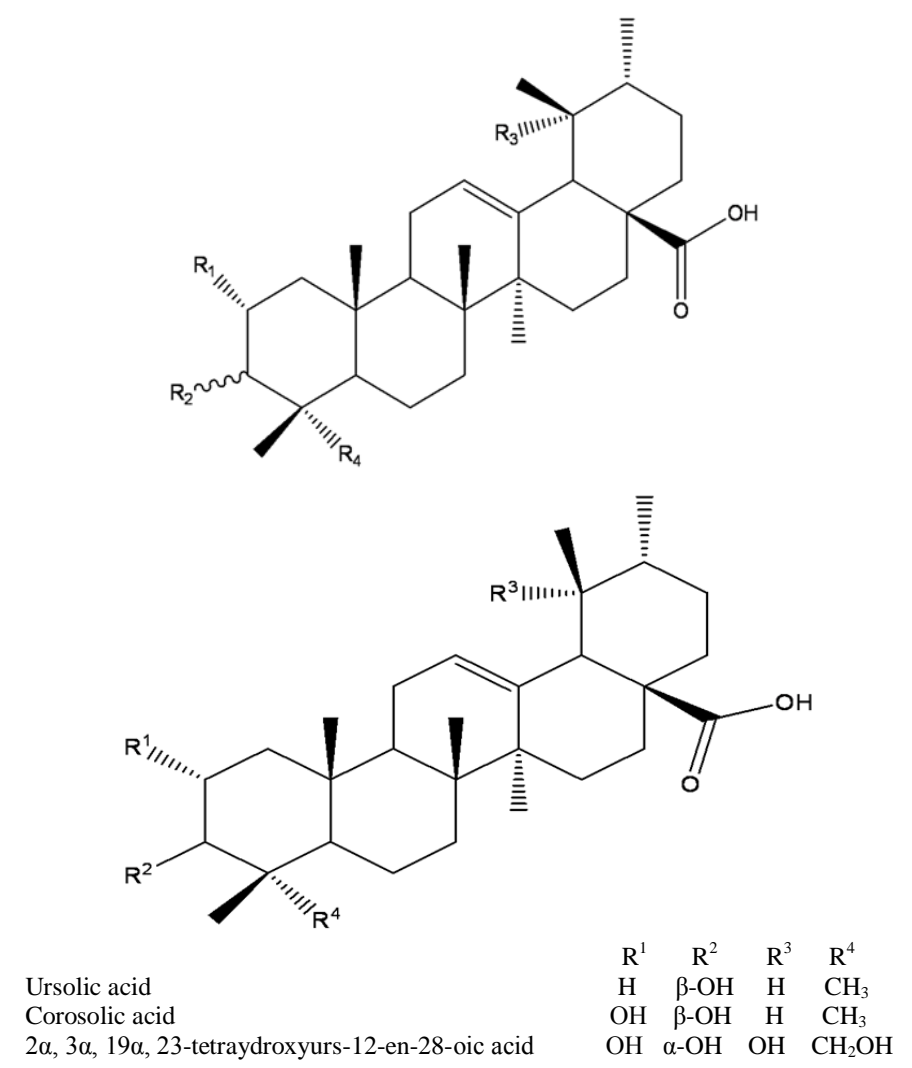

Figs. 3 \& 4: Structures of ursolic acid, corosolic acid and $2 \alpha, 3 \alpha, 19 \alpha, 23$-tetrahydroxyurs-12-en-28-oic acid.

\section{Seeds}

The seeds of $S$. paniculata contain $21 \%$ protein and $52 \%$ of oil on dry basis. The fatty acid composition of the oil contains $6 \%$ saturated fatty acids, $53 \%$ oleic and $36 \%$ linoleic acid ${ }^{22}$.

\section{Root}

The butyl alcohol extract of root of S. chinensis exhibited six new triterpenoid saponins. Their structures were established as symplocososides A to $\mathrm{F}^{23}$ (Fig.5). Symplocososide A (Fig.6) was obtained as a white amorphous powder and had a 
molecular formula of $\mathrm{C}_{63} \mathrm{H}_{100} \mathrm{O}_{23}$ which was determined from its positive ion High-resolution electro spray ionisation mass spectrometry (HRESIMS) and confirmed by ${ }^{13} \mathrm{C}$ Nuclear
Magnetic Resonance and Distortionless Enhancement by Polarization Transfer (DEPT) analysis and other fractions such as G-K have more significant functions (Fig.7).

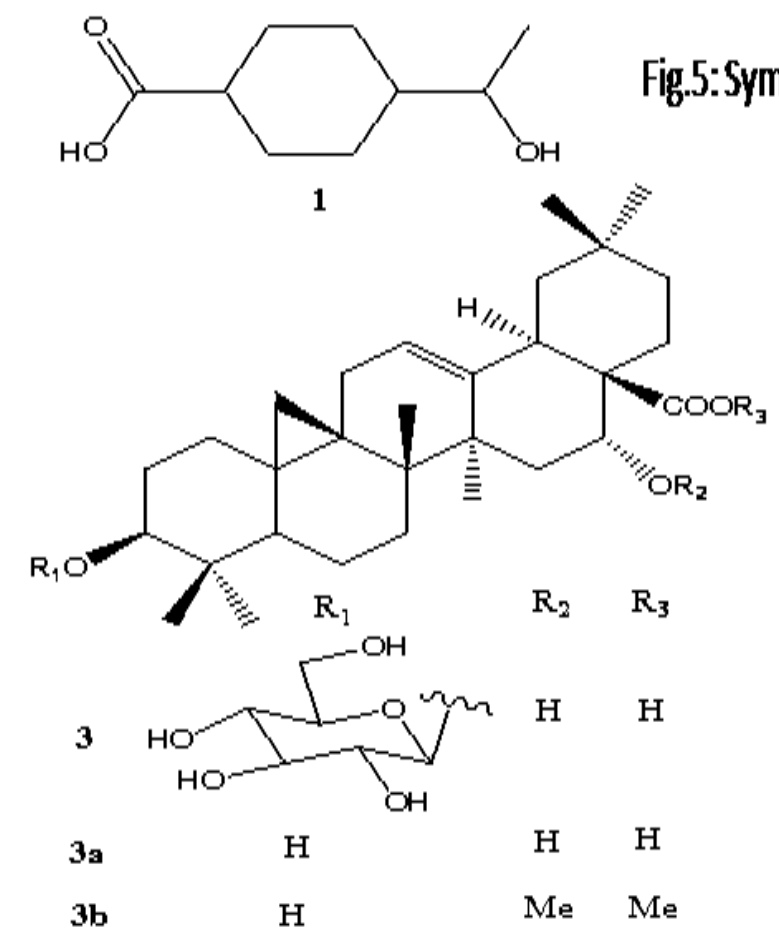<smiles>[R2][R]#[R][R]</smiles><smiles>[R6][C@H]1CC[C@]23C[C@]24CC[C@@]2(C)[C@@H](CC=C3C1)[C@@]4([2H])CC[C@@H]2[C@@H](C)/C=C\CC</smiles>

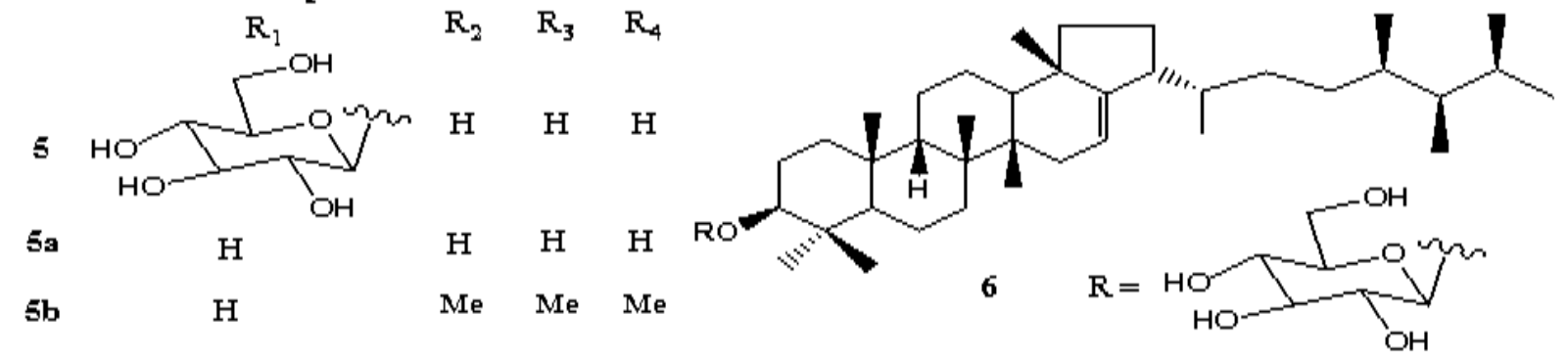<smiles>[R]Oc1cc2oc(-c3cc(OC)c(OC)c(OC)c3)cc(=O)c2cc1OC</smiles>

6a $\quad \mathrm{R}=\quad \mathrm{H}$

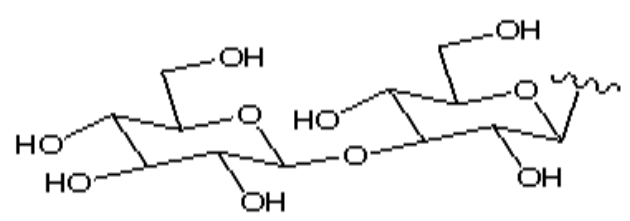
$7 \mathbf{a} \quad \mathrm{R}=$

$\mathrm{H}$ 


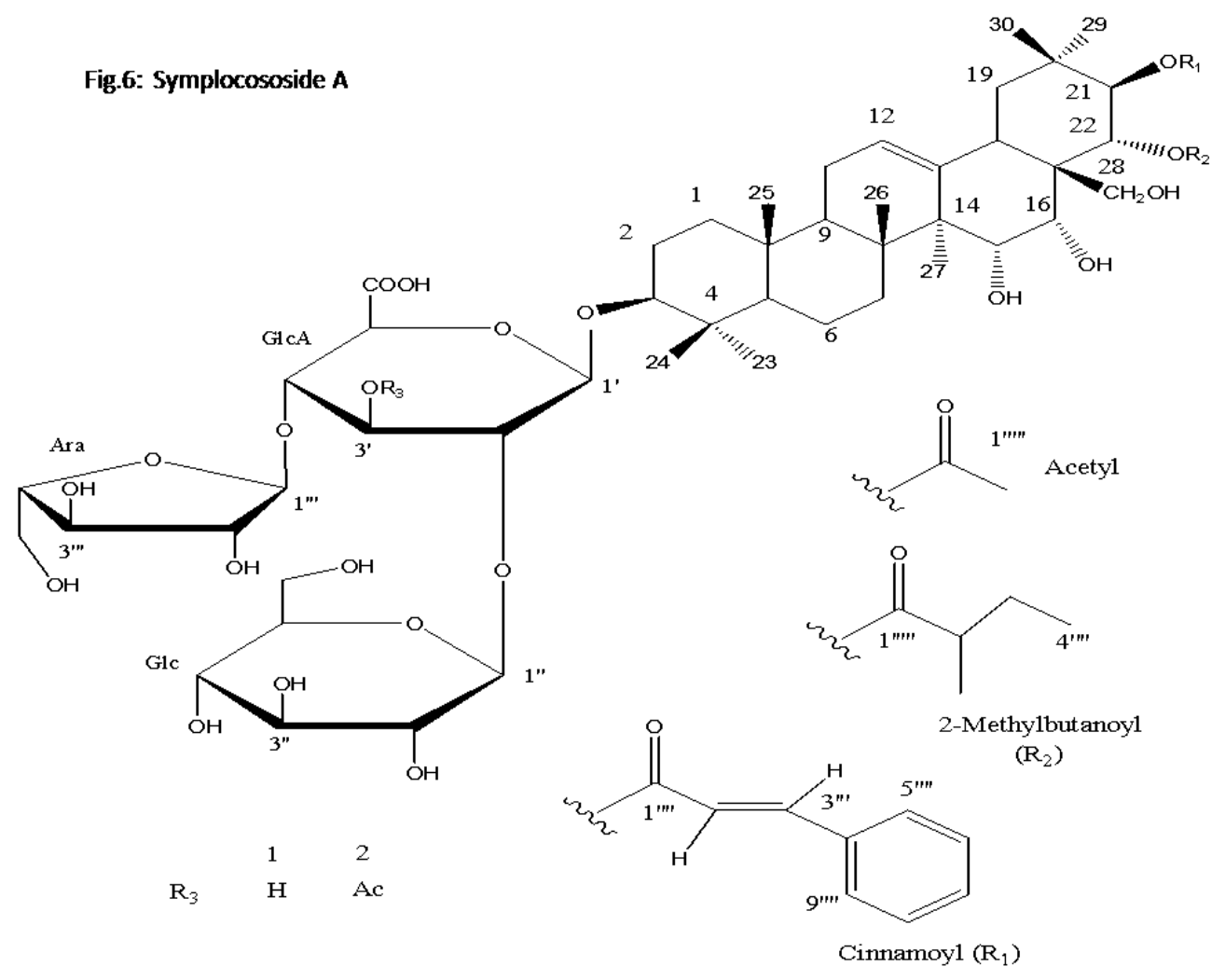

Symplocososide G-K

Fig.7:Symplocososide G-K
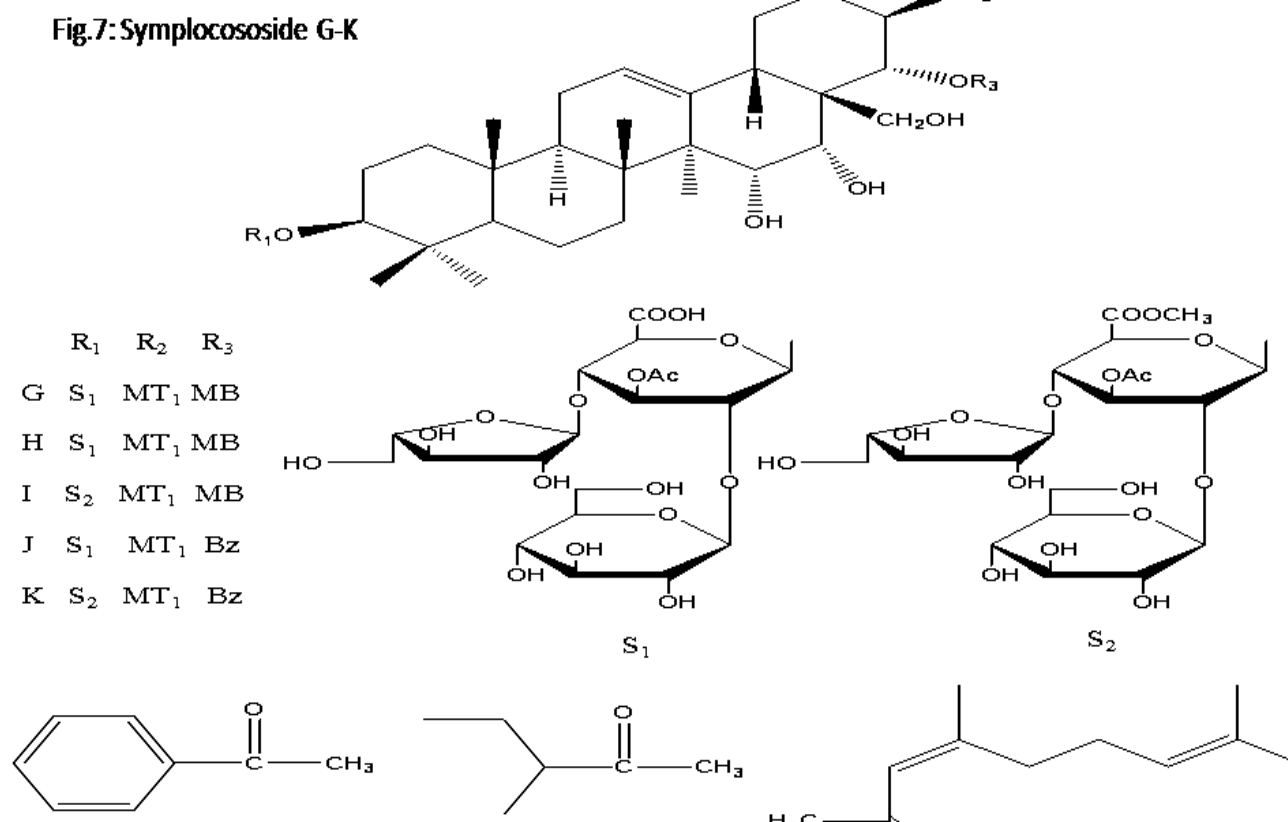

$\mathrm{Bz}$
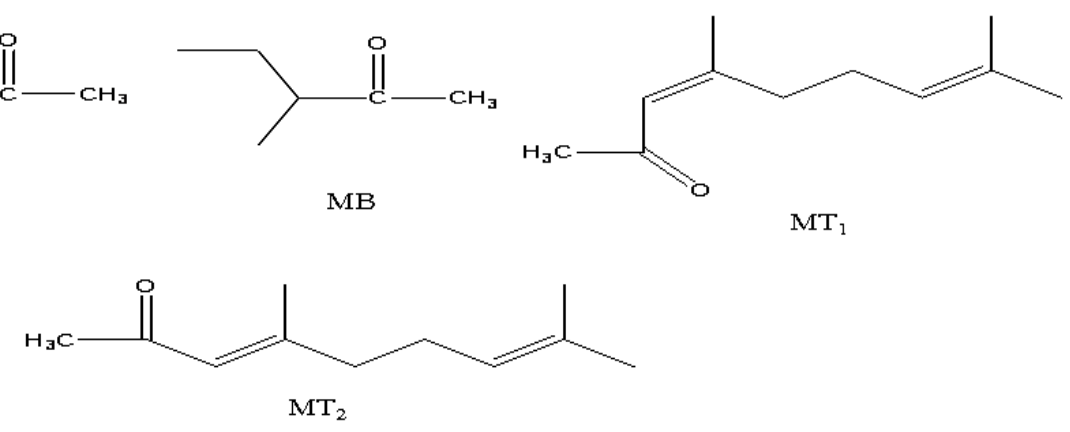


\section{Leaves}

The leaves of $S$. paniculata, yielded 4 compounds (Fig.8) namely octacose-1-ene (8a), stigmasterol (8b) and lupeol (8c) and salirepin D (8d) on solvent extraction $^{24}$.

\section{Stem bark}

The stem bark of the plant afforded seven compounds,4-(8-hydroxyethyl) cyclohexan-1-oic

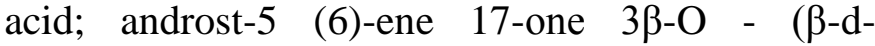
glucopyranoside); $9 \beta, \quad 25$-cyclo $3 \beta-O-(\beta-D$ glucopyranosyl)-echynocystic acid; $9 \beta, 19-$-cyclo

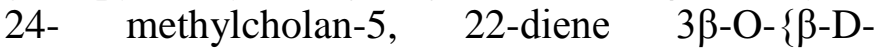
glucopyranosyl $(1 \rightarrow 6) \quad \alpha$-L- rhamnopyranoside $\}$;

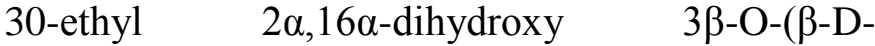
glucopyranosyl) hopan-24-oic acid; 32, 33, 34trimethyl-bacteriohopan-16-ene 3-O- $\beta$-Dglucopyranoside and flavone 3,, 4,, 5,, 6tetramethoxy 7-O- $\beta$-D-glucopyranosyl $(1 \rightarrow 3) \beta$-Dglucopyranoside $^{25}$ (Fig.9).
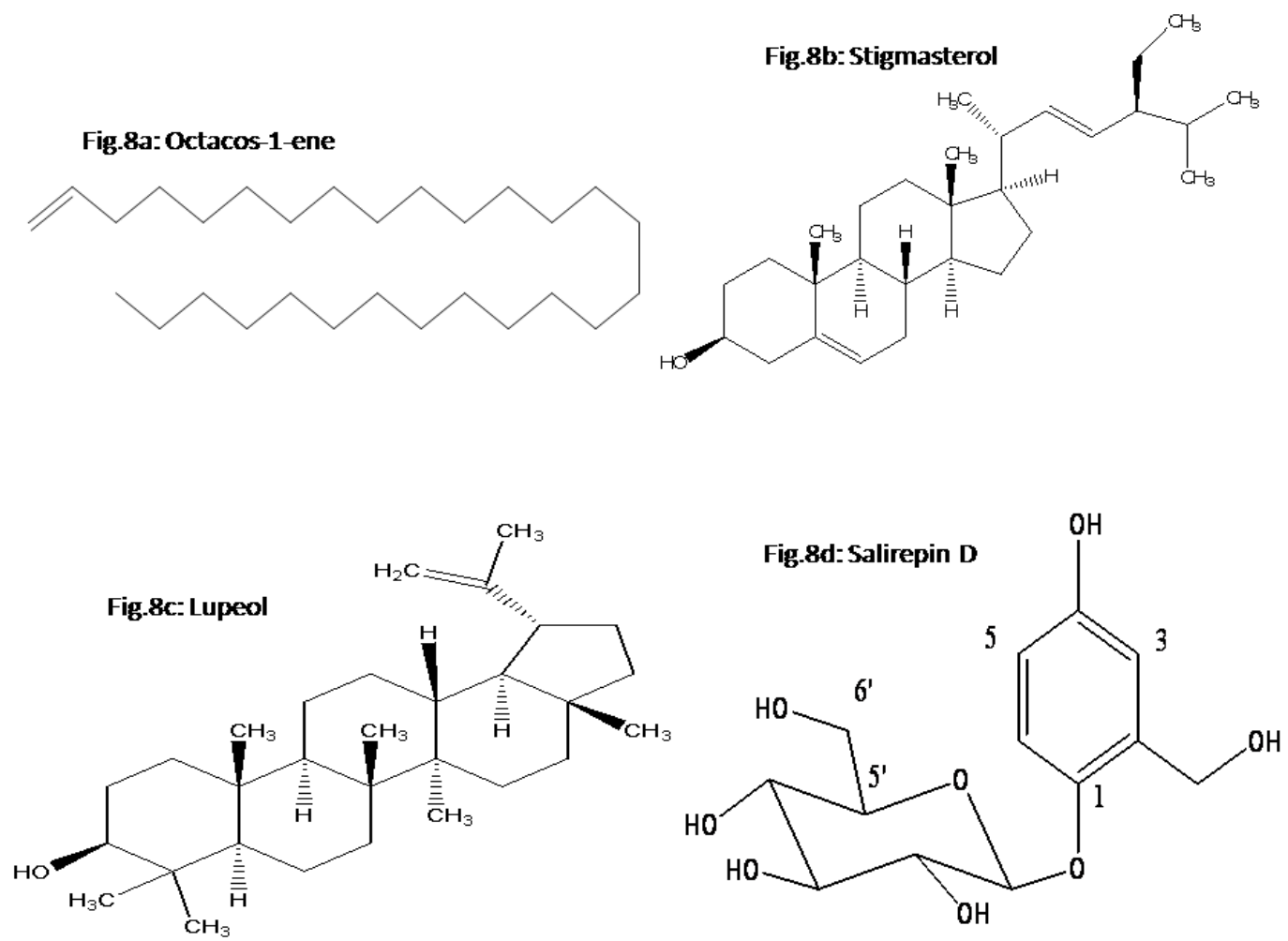

\section{Medicinal uses}

The members of genus Symplocos are gaining popularity due to their diverse biological activities and are well known for their traditional uses in the treatment of various diseases like leprosy, gynaecological disorders, ulcers, leucorrhoea, menorrhagia, malaria, tumefaction, bacterial diseases, diarrheoa, dysentery, eye diseases, hemorrhagic gingivitis, nephritis, bowel complaints, enteritis, snake bite and detoxification, particularly for anti-HIV, anti - tumor, and phosphodiesterase inhibitory activities ${ }^{2,26-30}$ The juice of the bark is applied externally to sprains and muscular swellings ${ }^{31}$.The important preparations using the drug are Nyagrodhadi Kwatha Curna ${ }^{32}$.

\section{Ethno-veterinary use}

The plant forms an ingredient of a herbal animal health product, NEBLON, useful in scours and non specific diarrhea in cattle and sheep. $\mathrm{LD}_{50}$ studies on Neblon indicated that it is free from any toxic effect. The spasmolytic activity of neblon for reducing intestinal peristalsis was comparable to standard drugs, atropine sulphate 
and its analogue, tropanyl ${ }^{33}$.

\section{Toxicology}

$S$. chinensis is a toxic herb distributed in southern China $^{29}$. When used in large quantity it causes dizziness, chest oppression and gastrointestinal disorder $^{38}$.

\section{Other uses}

Fruit is the edible part. It is cooked. Used in Jams, jellies and sauce ${ }^{34,35}$.It is used as a dye, mordant and wood. A yellow or red dye is obtained from the leaves and bark. Leaves serve as fodder for sheep and goats and it is recommended for turning and for carving if properly seasoned ${ }^{31,36-37}$.

Fig.9: Structures of seven compounds from stem bark

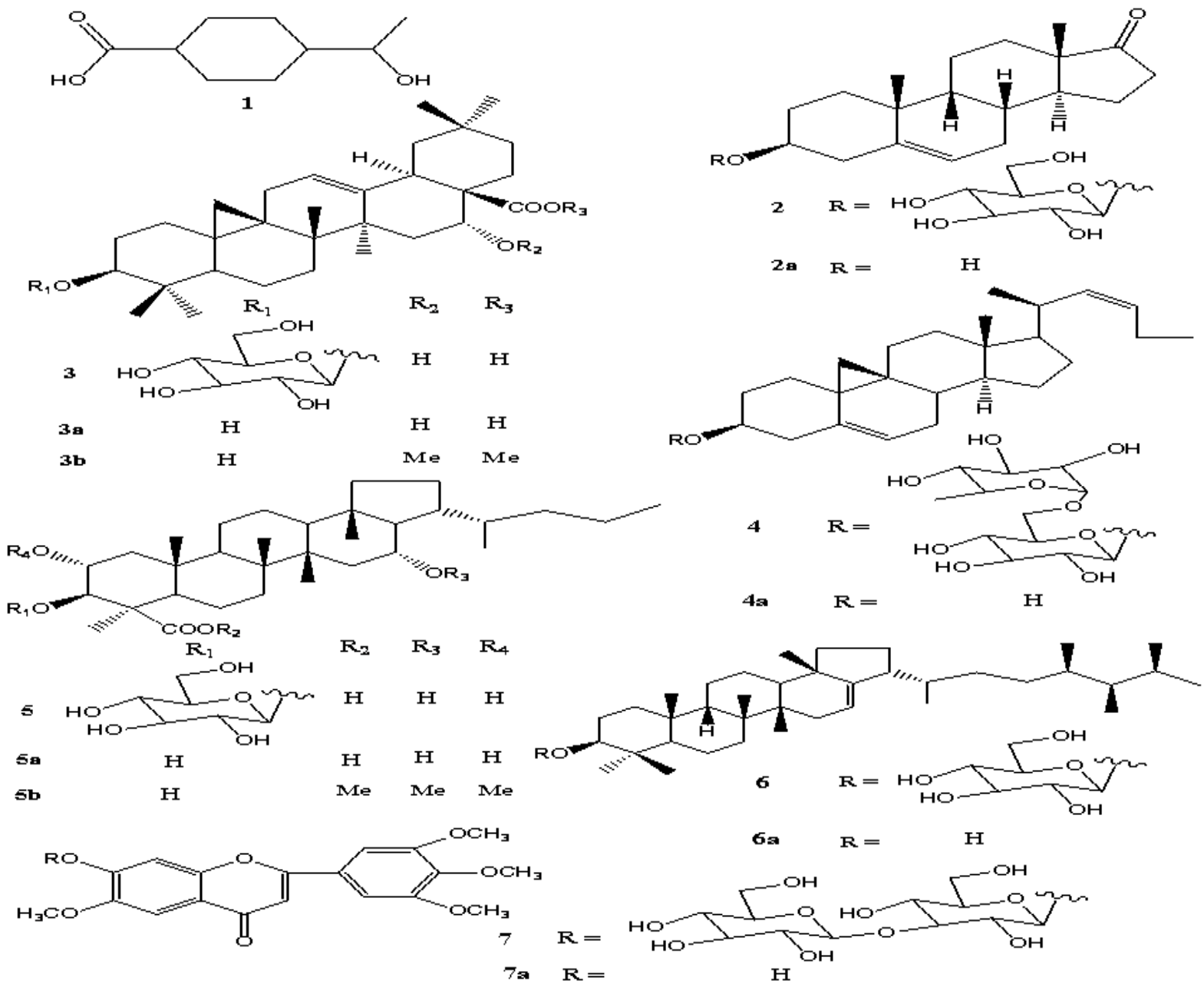

\section{Pharmacological activities}

\section{Anti cancerous activity}

Terpenoids are the major constituents within the genus Symplocos and most of them exhibit antiproliferative effects ${ }^{15,30}$. Six triterpenoid saponins, symplocososides A-F isolated from S. chinensis, shown to have anti-proliferative activity. Among them, symplocososide A exhibited activity against KB, HCT-8, A 549, BGC-823, and HELF cells ${ }^{39}$. Ursane-type triterpenes, in particular ursolic acid and corosolic acid, have been reported to possess a anti-tumor and anti-angiogenic activities ${ }^{40-41}$. The Ethyl alcohol soluble extract exhibited significant cytotoxic activities and four triterpenoids (Fig. 10a-10d) have been found from this fraction ${ }^{28}$. 
An ursane triterpenoid, $2 \beta, 3 \beta, \quad 19 \alpha, \quad 24-$ tetrahydroxy-23-norurs-12-en-28-oic acid (Fig.11), isolated from the root of $S$. chinensis, exhibited significant cytotoxic activity against B16 and BGC-

Fig.10a: 2a, 3 $3,19 a, 23$-tetrahydroxyurs 12-en-28-oic acid

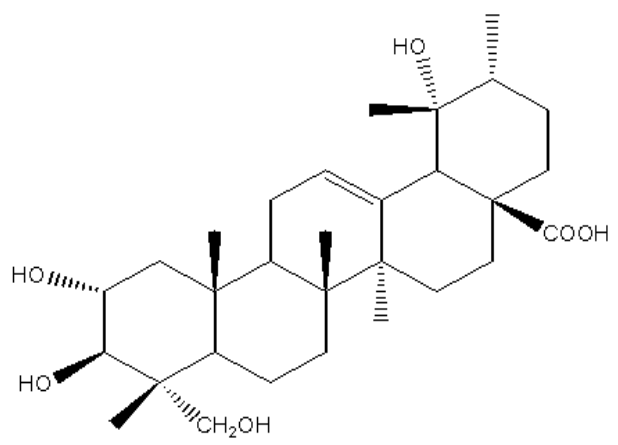

Fig 10c: 2a, 3a, 19a, 23-tetrahydroxyurs-12en-28-oic acid
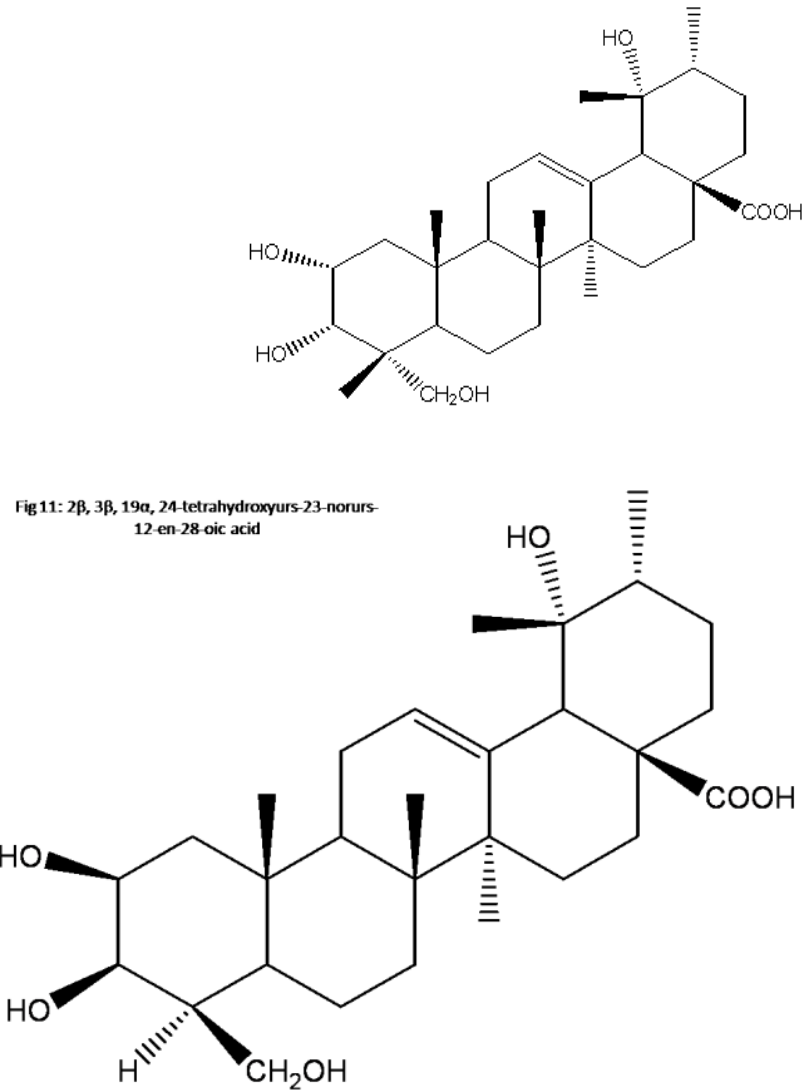

\section{Cytotoxicity}

A new triterpenoid isolated from the roots of $S$.
823 cells $^{29}$. Symplocososide C showed cytotoxic activity against HCT-8 cells and BGC-823 cells, and symplocososide $\mathrm{F}$ was found to be cytotoxic against HCT-8 cells ${ }^{39}$.

Fig.10b:3-oxa-19 a, 23, 24

trihydroxyurs-12-en-28-oic acid

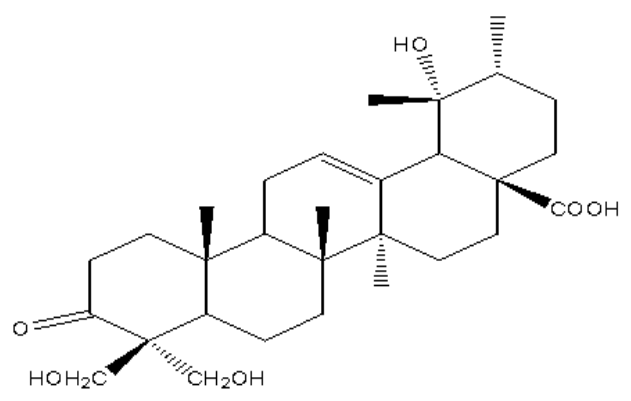

Fig 10d: 24-Hydroxytormentic acid

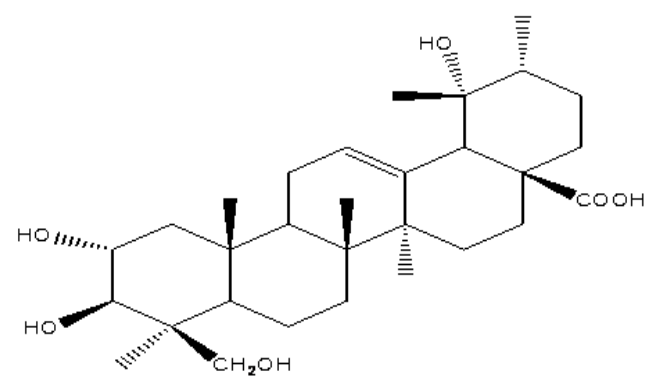

chinensis have strong antitumor activities ${ }^{29}$. Triterpenoid saponins from the roots have symplocososides $\mathrm{G}-\mathrm{K}$ which exhibited significant cytotoxic activities against some tumor cell line ${ }^{40}$. A new triterpene with strong cytotoxic activities was isolated along with three known triterpenes from the ethyl alcohol soluble fraction ${ }^{29}$.

\section{Antioxidant activity}

The relationship between antioxidant capacity and total phenolic content of the fruit of $S$. paniculata was estimated in water and fat soluble fraction. It was found that the fruit has potential rich resources of natural antioxidants, and could be developed into functional foods or drugs for the prevention and treatment of diseases caused by oxidative stress. 
The methanolic extract of $S$. paniculata was primarily assessed for its antioxidant activity against 1, 1-diphenyl-2-picylhydrazyl (DPPH). Reducing power assay was assessed in the fat and water soluble fractions of S. paniculata ${ }^{41}$.

\section{Anti-poisonous activity}

The phenolic glycoside derivatives showed inhibitory activity against snake-venom phosphodiesterase-I and human nucleotide pyrophosphatase phosphodiesterase I. The methanol extract of leaves and stem of $S$. paniculata showed in vitro PTP1B inhibitory activity. This extract was subjected to chemical analysis and afforded three ursane-type triterpenes, ursolic acid, corosolic acid, and $2 \alpha, 3 \alpha, 19 \alpha, 23-$ tetrahydroxyurs-12-en-28-oic acid (Fig.10) which inhibited PTP1B. Kinetic studies suggest that ursolic acid is a competitive inhibitor whereas corosolic acid is a mixed-type inhibitor of PTPIB ${ }^{17}$.

\section{Anti-diabetic activity}

Protein tyrosine phosphatase (PTPs), which dephosphorylate the tyrosine residues of proteins, play an important role in intra-cellular signaling and metabolism. Although several PTPs such as PTP $\alpha$, leukocyte antigen-related tyrosine phosphatase and $\mathrm{SH}_{2}$-domain-containing phosphotyrosine phosphate have been implicated in the regulation of insulin signaling, there is substantial evidence supporting PTPIB as the critical PTP controlling the insulin signaling pathway $^{16,42}$.

Corosolic acid, a component of $S$. paniculata improves insulin pathway. The action of Insulin is mediated by tyrosine phosphorylation and initiated by the binding of insulin to the insulin receptor. It may act as an insulin sensitizer, enhancing insulin receptor $\mathrm{B}$ phosphorylation indirectly by inhibiting certain non receptor protein tyrosine phosphatases $^{43}$. Corosolic acid may also enhance GLUT4 glucose transporter processing of glucose uptake into muscle cells ${ }^{44}$. Another study reported that corosolic acid inhibited gluconeogenesis by increasing the production of the gluconeogenic intermediate fructose-2, 6-bisphosphate in isolated hepatocytes. Corosolic acid may promote glycolysis $^{45,46}$. Treatment with corosolic acid lowered plasma insulin levels and reduced the blood glucose levels in KK-Ay mice, after a single oral dose was reported ${ }^{47}$. Another experiment showed similar inhibitory action against increasing blood glucose levels and also increasing the concentration of corosolic acid may lead to enhanced glucose uptake activity ${ }^{48,49}$. Corosolic acid induced muscle GLUT4 translocation from low-density microsomal membrane to plasma membrane in genetically-induced type-2 diabetic mice $^{44,46}$.

\section{Antimicrobial activity}

Ethanolic extract of leaves showed activity against Entamoeba histolytica strain STA Ascardia galli ${ }^{18,}$

34. S. paniculata plant has been used in bacterial infections ${ }^{25}$. The ethanolic extract of stem bark as well the compounds isolated from the fractional distillation showed anti-bacterial activity against Staphylococcus aureus, Bacillus subtilis, Pseudomonas auroginosa and Escherichia coli ${ }^{25}$. The compounds 3 and 5 isolated from stem bark showed a good antimicrobial agent and could be an alternate to the antibiotics in the treatment of infections caused by these microorganisms since most of them have developed resistance against the known antibiotics ${ }^{50}$. The extract of $S$. paniculata proved to have a potent antimicrobial activity ${ }^{25}$. Ethanolic extract of leaves showed anti-bacterial activity against Entamoeba histolytica and Ascardia galli $^{51}$.Corosolic acid, a component of S. paniculata showed a synergistic activity with tobramycin against $P$ seudomonas aeruginosa ${ }^{52}$.

\section{Action on lipid metabolism}

Corosolic acid was reported to have antihypertensive and lipid lowering. A study on rats showed that a reduced serum free fatty acid levels by corosolic and in turn controls the blood pressure $^{53}$. There is an in vitro evidence for corosolic acid inhibiting protein tyrosine phosphate 
1B. This phosphatase play an important role in the control of obesity ${ }^{16}$. It is a pancreatic lipase inhibitor; it is a key enzyme in the absorption of lipids ${ }^{54}$. Also a study in mice revealed that the corosolic acid acted as a peroxisome proliferator activated receptor alpha agonist, regulating lipid metabolism and increasing fatty acid beta-oxidation in the liver ${ }^{55}$.

\section{Anti-inflammatory activity}

The paste of the bark of S.paniculata used in the treatment of inflammation in traditional medicine but no scientific evidences available yet. The plant contains various triterpenoids exhibited potent antiinflammatory activities ${ }^{56,57}$. Crude extract and isolated compounds from stem bark of $S$. paniculata showed a dose-dependent inhibition of swelling caused by carrageenan induced inflammation in rats ${ }^{25}$. Corosolic acid acted against the classical pathway of the complement system is documented ${ }^{58}$.

\section{Conclusion}

The genus Symplocos is widespread all over the world, and many species of this genus have been used as traditional medicines for various ailments. These plants are well known for their traditional uses in leprosy, gynecological disorders, ulcers, leucorrhoea, malaria, nephritis, snake bite, menorrhagia, etc. The earlier reports on chemical investigation and pharmacological evaluation showed that the members of genus Symplocos contain a number of bioactive novel compounds of different nature like terpenoids, flavonoids, lignans, phenols, steroids, alkaloids, iridoids, etc. Among them, terpenoids (Symplocososides A-C, ursolic acid, corosolic acid, etc), flavonoids, lignans, phenols, alkaloids are potent bioactives. Despite many researches on the plants of this genus, a number of plants are yet chemically and pharmacologically unknown. Hence, a detailed study is required to understand the structure-activity relationship of these constituents. As the literature showed, many plants extracts have cytotoxic, diabetic, anti-HIV activities; hence, the particular constituents responsible for the activities may be isolated for further process. In addition, some plant extracts were only screened for their preliminary in vitro activities, so the advanced clinical trial of them deserves to be investigated further. Herein, we described the possible applications in clinical research, but further investigations on phytochemical discovery and subsequent screening are needed for opening new opportunities to develop pharmaceuticals based on Symplocos constituents.

The properties of $S$. paniculata are same as of $S$. recemosa, but of the two species $S$. paniculata is better therapeutically (Ayurveda). In Ayurvedic literature, Akshi bheshaja (medicine for eye) term is used as synonym for lodhra. So far no research data is available on the role of $S$. paniculata in eye diseases. This area needs to be explored.

Lodhra should be used either in powder or decoction form. Alcoholic or aqueous extracts of lodhra kept for some time gets deteriorated and becomes physiologically inert. In all the diseases, in which this drug was tried under the auspices of the Indigenous Drugs Committee-the result was poor or negative as the drug was administered in liquid extract form. Hence, shelf-life studies are more important to evaluate its biological activity in all forms. Further study is needed to find out the various metabolic disorders that can be treated using isolated chemical constituents with demonstrated activities.

Pharmacognostical standards are available for other species of Symplocos but published data does not exist currently for $S$. paniculata. The microstructures will be recognized as a tool to measure the phylogenetic relationship to resolve the taxonomic controversies. The part of pharmacognostic review and phytochemical analysis will help to establish the botanical identity of this plant that could be made use of those who deal with the species and also in the quality assurance of this plant species. Some of the pharmacological and therapeutic activities are scientifically reported for this plant. These 
investigations needs to be further studied for their meaningful extension in clinical usage. This review article will stimulate further research in the field of phytochemistry, pharmacology and also in the clinical application of phytochemical constituents of Symplocos paniculata.

\section{Conflict of interest statement}

Author declares that there is no conflict of interest.

\section{References}

1. Hegnauer R. Chemotaxonomie derPflanzen, Band VI, Birkh Nuser Verlag, Basel, Stuttgart, 1973: 478.

2. Kirtikar KR, Basu BD. Indian Medicinal Plants. Vol. II, $2^{\text {nd }}$ Ed. 1510-1511.

3. Singh TB, Chunekar KC. Glossary of Vegetable drugs in Brhattrayi. Chaukhambha Amarabharati Prakashan, Varanasi, $2^{\text {nd }}$ Ed.1999: 351-352.

4. Sivarajan VV, Indira B. Ayurvedic Drugs and their Plant Sources. Oxford \& IBH Publishing Co. Pvt. Ltd., New Delhi, 1994: 279.

5. www.tropicos.com

6. Chopra, R.N., Nayar, S.L. and Chopra, I.C. 1956. Glossary of Indian medicinal plants. CSIR, New Delhi. P. 237.

7. Polunin O. Stainton A. Flowers of the Himalayas. Oxford University Press, 1984.

8. Thomas GS. Ornamental Shrubs, climbers and bamboos. Murray 1992.

9. Huxley A. The new RHS Dictionary of Gardening. MacMillan Press, 1992.

10. Bean W. Trees and Shrubs Hardy in Great Britain. Vol.1-4 and Supplement. Murray 1981.

11. Shen, R \& Xue, F (1991) Biology of Pidorus euchchromioides Walker. Entomological Knowledge 28, 29-31(in Chinese).

12. Fangsen $X$, Kallenborn $H$ G.Control of summer and winter diapauses in pidorus euchromioides (Lepidoptera:Zygaenidae) on Chinese sweetleaf Symplocos chinensis. Bulletin of Entomological Research 1998;88:207-211.
13. Sheat WG. Propagation of Trees, Shrubs and Conifers. MacMillan and Co. 1948.

14. Wang et al. 2004

15. Badoni R, Semwal DK, Sudhir K. Kothiyala SK, Rawat U. Chemical constituents and biological applications of the genus Symplocos. Journal of Asian Natural Products Research, 2010; 12(12)1069-1080.

16. Na, M. Yang, S., He, L., Oh, H., Kim, B.S., Oh, W.K., Kim, B.Y., Ahn, J.S., 2006. Inhibition of protein tyrosine phosphatase 1B by ursane-type triterpenes isolated from Symplocos paniculata. Planta Medica 72, 261-263.

17. Dandiya PC, Chopra YM, Banerjee SP. Indian Journal of Pharmacy, 1966; 28:344.

18. Higuchi R, Kawasaki T, Momota B, Pandey VB, Dasgupta B. (1982), Phytochemistry 21, 907-910.

19. Tanaka T, Kawamura K, Kohda H, Yamasaki K, Tanaka O. (1982), Chem. Pharm. Bull. 30, 2421-2426.

20. Iida I, Hayashi M, Murata T, Ono M, Inoue K, Fujita T. (1990), J. Chromatogr. 515, 503509.

21. Inoryi H, Takeda Y, Nishimuna H. (1973), Yakugaku Zasshi 93, 44-49.

22. Earle et al., Journal of American oil chem.Society, 1960;37:440

23. Tang D, Shen $\mathrm{Hu}, \mathrm{S}$ Gao, Yu. Cytotoxic triterpenoid saponins from Symplocos chinensis. J. Nat. Prod. 67, 1969 (2004).

24. Naveen K, Jangwan JS. Phytoconstituents of Symplocos paniculata (leaves).Journal of current chemical and Pharmaceutical Sciences.2012; 2(1):76-80.

25. Semwal RB, Semwal DK, Semwal R, Singh $\mathrm{R}$, Rawat MSM. Chemical constituents from the stem bark of Symplocos paniculata Thunb. with antimicrobial, analgesic and anti inflammatory activities. Journal of Ethnopharmacology, 2011; 135: 78-87.

26. Khan MR, Kihara M, Omoloso AD 2001. Antimicrobial activity of Symplocos cochinensis. Fitoterapia 72: 825-828.

27. Ali M, Bhutani KK, Srivastava TN. Triterpenoids from Symplocos racemosa bark. 
Phytochemistry 29, 3601-3604 (1990).

28. Dhaon R, Jain GK, Sarin JPS, Khanna NM. (1989). Symplocoside, a new antifibrinolytic glycoside from Symplocos racemosa. Indian Journal of Chemistry B.28, 982-983.

29. Li XH, Shen DD, Li N and Yu SS. Bioactive triterpenoids from Symplocos chinensis. Journal of Asian Nat. Prod. Res, 2003; 5:4956.

30. Huo CH, Shen LR, Zhao, YY, Liang H. Chem. Biodiver, 2007; 4:1.

31. Manandhar NP. Plants and People of Nepal Timber Press, Oregon, 2002.

32. The Ayurvedic Formulary of India, Part I, $2^{\text {nd }}$ Edition, Government of India, New Delhi, 2003; p.57.

33. Srivastava DN, Bhatt KR. Indian J. Indigen. Med, 1993; 10: 23.

34. Kunkel G. Plants for Human Consumption, Koeltz Scientific Books, 1984.

35. Facciola S. Cornucopia-A Source Book of Edible Plants, Kampong Publications, 1990.

36. Gamble JSA. Manual of Indian Timbers, Bishen Singh Mahendra Pal Singh, 1972.

37. Gupta BL. Forest Flora of Chakrata, Dehra Dun and Saharanpur, Forest Research Institute Press, 1945.

38. Guo XZ, You-du-zhong-cao-yao-da-cidian.Tianjin Translation for Science and Technology Co., Tianjin, 1992:223-224.

39. Tang MJ, Zhao J, Li XH,Yu SS. China J. Chin. Mater. Med. 29, 390, (2004).

40. Fu GM, Wang YH, Gao S, Tang, MJ; Yu SS. Five New cytotoxic triterpenoid Symplocos chinensis. Planta Med. 2005, 71, 666-672.

41. Fu L, Xu BT, Xu XR, Qin XS, Gan RY, Li HB. Antioxidant capacities and total phenolic contents of 56 wild fruits from South China. Molecules 2010; 15:8602-8617.

42. Johnson TO, Ermolieff J, Jirousek MR. Protein tyrosine phosphatase 1B inhibitors for diabetes. Nat Rev. Drug Discov.2002; 1:696709.

43. Shi L. Zhang W, Zhou YY, et al. Corosolic acid stimulates glucose uptake via enhancing insulin receptor phosphorylation. Eur $\mathbf{J}$ Pharmacol.2008; 584(1):21-29.
44. Miura T, Itoh Y, Kaneko T, et al. Corosolic acid induces GLUT4 translocation in genetically type 2 diabetes mice. Biol Pharm Bull.2004; 27(7):1103-1105.

45. Yamada K, Hosokawa M, Fujimoto S, et al. Effect of corosolic acid on gluconeogenesis in rat liver. Diabetes Res Clin Pract.2008:80(1):48-55.

46. Klein G, Kim J, Himmeldirk K, Cao Y, Chen $\mathrm{X}$. Antidiabetes and anti-obesity activity of Lagerstroemia speciosa. Evid Based

47. Miura T, Ueda N, Yamada Y, et al. Anti diabetic effects of corosolic acid in KK-Ay diabetic mice. Biol Pharm Bull.2006; 29(3):585-587.

48. Matsuyama F, Seino Y, Yamada Y et al., Corosolic acid and its analogs as oral gluconeogenesis inhibiting agents. US Patent WO 2005-JP8569, April 28, 2005.

49. Zong W, Zhao G, Corosolic acid isolation from the leaves of Eriobotrta japonica showing the effects on carbohydrate metabolism and differentiation of 3T3-L1 adipocytes, Asia Pac J Clin Nutr. 2007; 16 (1): 346-352.

50. Singleton P, (1999). Bacteria in Biology, Biotechnology and Medicine, Fourth ed. John Wiley and Sons Ltd., New York, 333-338.

51. Dhar et al, Indian Journal of experimental Biology, 1968; 6:232.

52. Garo E, Eldridge GR, Goering MG, et al., Asiatic acid and corosolic acid enhance the susceptibility of Pseudomonas aeruginosa biofilms to tobramycin. Antimicrob agents Chemother, 2007; 51 (5): 1813- 1817.

53. Kunitomo M. Oxidative stress and atherosclerosis. 2007; 127 (12): 1997-2014.

54. Jang DS, Lee GY, Kim J et al. A new pancreatic lipase inhibito risolated from the roots of Actinidia arguta. Arch Pharm Res, 2008; 31 (5): 666-670.

55. Yamada K, Hosokawa M, Fujimoto S, et al. Effect of corosolic acid on gluconeogenesis in rat liver. Diabetes Res Clin Pract.2008:80(1):48-55.

56. Wang, J.R., Zhou, H., Jiang, Z.H., Yuen, F.W., Liu, L., 2008. In vivo anti-inflammatory 
and analgesic activities of a purified saponin fraction derived from the root of Ilex pubescens. Biological and Pharmaceutical Bulletin 31, 643-650.

57. Puangpraphant, S., Mejia, E.G.D., 2009. Saponins in Yerba Mate tea (Ilex paraguariensis A. St. -Hil) and quercetin synergistically inhibit iNOS and COX-2 in lipopolysaccharide-induced macrophages through NF $\kappa \mathrm{B}$ pathways. Journal of Agricultural and Food Chemistry 57, 88738883.

58. Thuong PT. Min BS, Jin W, et al., Anticomplementary activity of Ursane type tri terpenoids from Weigela subsessilis. Biol Pharm Bull, 2006; 29 (4): 830-833.

\section{How to cite this article:}

Kusuma, G., Vijaya Kumar, B., Chitra, S., 2018. Symplocos paniculata Miq.-A Review. Int. J. Curr. Res. Biosci. Plant Biol. 5(3), 7-20. doi: https://doi.org/10.20546/ijcrbp.2018.503.002 